Aquaculture

October 2018, Volume 495, Pages 831-841

http://dx.doi.org/10.1016/j.aquaculture.2018.06.075

http://archimer.ifremer.fr/doc/00445/55696/

(c) 2018 Elsevier B.V. All rights reserved.

\title{
Mortality investigation of Mytilus edulis and Mytilus galloprovincialis in France: An experimental survey under laboratory conditions
}

\author{
Benabdelmouna Abdellah ${ }^{1}$, Garcia Celine ${ }^{1}$, Ledu Christophe ${ }^{1}$, Lamy Pierre ${ }^{1}$, Maurouard Elise ${ }^{1}$, \\ Dégremont Lionel ${ }^{1, *}$
}

${ }^{1}$ Ifremer, RBE-SG2M-LGPMM, Station de la Tremblade, Avenue de Mus de Loup, F-17390 La

Tremblade, France

* Corresponding author : Lionel Dégremont, email address : Idegremo@ifremer.fr

\begin{abstract}
:
In the context of mass mortality outbreaks affecting adult and juvenile mussels since 2014 in France, two investigations were conducted to study mussel mortality under laboratory conditions in 2015 . The first investigated the horizontal transmission of a putative causal agent of the mortality among two stocks of wild Mytilus edulis and the potential genetic resistance of adults and their progenies. The second evaluated the resistance of pure and hybrid crosses of $M$. edulis and M. galloprovincialis at the spat stage to a mortality outbreak. For the first time in France, we described several mortality outbreaks affecting spat and adult mussels under laboratory conditions. Mortality was observed for seawater temperatures ranging from 10 to $23^{\circ} \mathrm{C}$, although the significant mortality outbreaks occurred between 12 and $17^{\circ} \mathrm{C}$ in adults and at $22^{\circ} \mathrm{C}$ in spat. The disease screening revealed that no notifiable pathogen agent, as defined by OIE, was detected in the analyzed moribund mussels. Although bacteria belonging to the Splendidus clade were detected at high prevalence, with the exception of a mortality outbreak occurring in August, their role could not be defined in this study. Survivors of a mortality event occurring in the field in 2014 (Yves stock) still exhibited around 30\% of mortality in 2015 under laboratory conditions, which indicated that they were either not fully resistant or that susceptibility varies with mussel age/size. This finding also suggests that a part of the survivors (or all) were carriers of a putative causal agent of the mortality. We demonstrated the horizontal transmission of a putative causal agent from the Yves stock to another stock of wild adult mussels (stock Agnas) which experienced $46 \%$ of mortality. In contrast, the Agnas stock had low mortality (5\%) in the separate condition. Horizontal transmission of a putative causal agent from the wild adults to their hatchery-produced progenies was also observed. The progenies of the Yves stock, which survived a mortality outbreak in 2014, had lower mortality (27\%) than those of the unselected Agnas stock $(68 \%)$. Similarly, low mortality $(<20 \%)$ were reported at the spat stage for a second stock of $M$. edulis produced from survivors of a mortality outbreak as well as for $M$. galloprovincialis, whereas their interspecific hybrids had mortality around $30 \%$. These results could suggest that selective breeding programs in $M$. edulis, or the cultivation of $M$. galloprovincialis rather than $M$. edulis, could both reduce the impact of mortality outbreaks on mussel aquaculture. Nevertheless, further investigations are required to address the genetic basis of the survival in the two main mussels species cultivated in France.
\end{abstract}




\section{Highlights}

- M. edulis that survived a mortality outbreak continued to show mortality in the following year, Naïve $M$. edulis adults had significant mortality only when they were in contact with $M$. edulis that survived a mortality outbreak suggesting a horizontal transmission of a putative causal agent, No putative causal agent identified yet, although the bacteria belonging to the Splendidus clade were detected at high prevalence, $M$. edulis spat seems less susceptible than $M$. edulis adults to mortality, - M. edulis spat seems more susceptible than M. galloprovincialis spat to mortality,

Keywords : Mytilus edulis, Mytilus galloprovincialis, Interspecific hybrids, Mortality outbreaks 


\section{Introduction}

The blue mussel complex includes three commercially important marine mussel species (Mytilus edulis Linnaeus, 1758; Mytilus galloprovincialis Lamarck, 1819; Mytilus trossulus Gould, 1850) and has a worldwide distribution. In Europe, M. trossulus is believed to be confined to the Baltic, and there is no significant fishery or aquaculture involving this species. In contrast, aquaculture of M. edulis and M. galloprovincialis is extensive. These species are the most important mussel species in Europe, and their annual productions reach 496,000 metric tons (FAO, 2017). The two species are very closely related, and their taxonomic status is debated because they can interbreed in areas of co-occurrence and produce fully fertile hybrids that are morphologically and physiologically intermediate between the parental taxa. As a result, a patchy mosaic of pure species and hybrids occurs along thousands of kilometers of Atlantic coast from France to the Shetlands (Bierne et al. 2003). Additionally, despite some differences in shell shape, the identification of parental species and their reciprocal hybrids is challenging because of the extreme plasticity of morphology exhibited by mussels under environmental variation (Gosling 1992). However, since 1995, reliable genetic techniques (enzyme electrophoresis and PCR-based DNA methodologies) have been established allowing reliable identification for European populations of these species (Inoue et al. 1995; Daguin et al. 2001; Hilbish et al. 2002; Bierne et al. 2003).

In France, blue mussel (M. edulis and M. galloprovincialis) aquaculture is an important industry, with production varying from 65000 to 79000 metric tons during the last decade (FAO, 2017). The industry exclusively relies on natural spatfall, which is limited to the Atlantic coast, principally in the Pertuis Charentais zone and Bourgneuf Bay (Goulletquer and Héral. 1997). Since 2014, blue mussel production in France has faced sudden and unfamiliar mass mortality outbreaks (90-100\%) affecting both juvenile and adult blue mussels along the French Atlantic coasts (Bechemin et al. 2015; Polsenaere et al. 2017). While M. edulis has been 
experiencing high mortality since 2014 , the susceptibility of $M$. galloprovincialis has not been investigated yet. A pathogenic strain of Vibrio splendidus was isolated from moribund mussels sampled in 2014 (Polsenaere et al. 2017, Oden el al. 2016) as in some previous mortality events in 2010 (Ben Cheikh et al. 2015). Meanwhile, their roles on mortality outbreak in French cultured mussel populations are still unknown. In addition, recent studies indicated that the mortality level of blue mussel stocks in France appeared to be significantly correlated to genomic abnormalities detected by flow cytometric analyses of hemolymph (Benabdelmouna and Ledu 2016). These genomic abnormalities could be reflected environmental contaminations or also could be the sign of a potential disseminated neoplasia disease.

Mortalities of cultured blue mussels have already been reported as "summer mortality" in other locations in the world. The extent of mortality can be highly variable for different mussel stocks, even in the same environment (Fuentes et al. 1992; Fuentes et al. 1994, Myrand and Gaudreault 1995; Tremblay et al. 1998). Interestingly, as presented by Myrand et al. (2000), studies indicate that blue mussel mortalities are more strongly influenced by genetic factors (stock origin), whereas environmental conditions are more important in explaining the variance in growth.

Questions have arisen concerning the recently observed susceptibility of adult and juvenile mussels to these recent mass mortality outbreaks in France. One important interrogation concerned the impact of the genetic background of mussel stocks in relation to mussel life history and interspecific variability. To study the effects of genetic differences, it is necessary to use hatchery-produced seed that represent genetically divergent mussel populations but that share a common pre-transplantation environment. Thus, two investigations were conducted at the Laboratory of Genetics and Pathology of Marine Molluscs (LGPMM) Ifremer facilities in La Tremblade in 2015. The first investigation characterized two blue mussel stocks which were sampled from two sites in 2015: one site that was heavily impacted by mortality outbreaks in 2014 and one non-impacted site. The second investigation evaluated the potential genetic 
resistance to a mortality outbreak of the progenies of the two stocks as well as the resistance of pure and hybrid crosses between a third M. edulis population from the Pertuis Charentais sounds on the Atlantic coast and a M. galloprovincialis population from the Mediterranean coasts. The main objectives were to study the life-history of wild stocks and the possible horizontal transmission of a putative causal agent among them, and to investigate the possible effect of selective breeding and inter-specific crosses to reduce the impact of outbreaks on mussel aquaculture.

\section{Materials and Methods}

\subsection{Adult stocks}

Three wild adult stocks of mussels were sampled at the end of 2014. Two stocks consisted of M. edulis sampled at Agnas $\left(45^{\circ} 52^{\prime} 23^{\prime} \mathrm{N}, 1^{\circ} 10^{\prime} 15^{\prime \prime} \mathrm{W}\right)$ in the Marennes-Oléron Bay and at Yves $\left(46^{\circ} 0^{\prime} 26^{\prime} \mathrm{N}, 1^{\circ} 4^{\prime} 7^{\prime \prime} \mathrm{W}\right)$ in the Pertuis Charentais sounds, which were named "Agnas” and "Yves", respectively. The third wild stock was of M. galloprovincialis mussels that originated from the Mediterranean coasts (Bouzigues, Thau Lagoon) $\left(43^{\circ} 26^{\prime} 35^{\prime \prime} \mathrm{N}, 3^{\circ} 38^{\prime} 19^{\prime \prime} \mathrm{E}\right)$. To our knowledge, the wild M. edulis mussels of the Agnas stock and the M. galloprovincialis mussels from Thau Lagoon did not suffer any atypical mortality in 2014, whereas the mussels from the Yves stock experienced 50\% abnormal mortality of undetermined cause (Robert et al., 2015). All of the sampled wild stocks, comprising approximately 1,500 mussels each, were transferred to the Ifremer hatchery in La Tremblade and maintained in separate tanks until use. The average mussel weight was approximately $3 \mathrm{~g}$ for the Agnas stock, $6 \mathrm{~g}$ for the hatchery and Yves stocks and $10 \mathrm{~g}$ for Thau Lagoon stock.

Additionally, one hatchery-produced $M$. edulis stock produced and maintained at the Ifremer hatchery in La Tremblade was used. This stock was produced in 2013 from a mass spawn using approximately 100 wild mussels that were sampled from La Floride $\left(45^{\circ} 48^{\prime} 02^{\prime \prime N}, 1^{\circ} 09^{\prime} 03^{\prime \prime} \mathrm{W}\right)$ 
in 2012. During winter-spring periods of 2014, this stock exhibited a massive mortality outbreak (85-90\%) that was associated with the detection of bacteria belonging to Splendidus clade.

\subsection{Hatchery production of mussels}

Using one tank per stock, 100 to 300 mussels were placed in the conditioning room. Unheated UV-treated and filtered seawater (400 L per hour) was enriched with a cultured phytoplankton diet (Isochrysis galbana, Tetraselmis suecica and Skeletonema costatum). When the gonads were ripe, spawning of mussels was induced in March 2015 and, after spawning, the parents were returned to their respective tanks. A total of 6 cross types were obtained from the three wild stocks and the hatchery-produced stock of mussels (Table 1). For wild M. edulis crosses, batches were coded G0-Agnas and G0-Yves for offspring originating from 300 mussels and 160 mussels for the stocks sampled in "Agnas" and "Yves" sites, respectively. For intra- and inter-specific crosses, the parental individuals used were from the hatchery-produced stock of M. edulis (15 females and 25 males) and the wild stock of $M$. galloprovincialis (10 females and 15 males). Their progenies were coded EE for $M$. edulis intra-specific crosses and GG for $M$. galloprovincialis intra-specific crosses, whereas the hybrids from the two reciprocal crosses were coded EG and GE for $\odot$ M. edulis $\mathrm{x} \overbrace{}^{\lambda} M$. galloprovincialis and $q$ M. galloprovincialis $\mathrm{x}$ ${ }^{\lambda} M$. edulis, respectively (Table 1 ). The embryos were transferred in $150-\mathrm{L}$ tanks containing filtered and UV-treated seawater at $20^{\circ} \mathrm{C}$, which was changed 3 times per week. The larvae were fed daily with a mixture of algae (I. galbana, Chaetoceros gracilis, S. costatum). Larvae density was established at 10 larvae $\mathrm{mL}^{-1}$ on day 1 post-fertilization and then progressively reduced to limit competition to 5 and 3 larvae $\mathrm{mL}^{-1}$ on day 5 and 7 post-fertilization, respectively. At the pediveliger stage, the larvae were ready to settle; they were then transferred 
to the micronursery into $150-\mu \mathrm{m}$ sieve-bottomed trays using a downweller system at $20^{\circ} \mathrm{C}$. The seawater was enriched with a mixture of four algal species routinely produced at the hatchery (I. galbana, C. gracilis, T. suecica, and S. costatum). The sieves were washed daily and changed regularly depending on spat growth.

\subsection{Species identification}

Molecular differentiation of Mytilus taxa and their putative hybrids was conducted using a pair of primers developed by Inoue et al. (1995) to amplify a segment of gene coding an adhesive protein of byssus (Glu). The primers Me 15 and Me 16 produce three PCR products that differ in length among the three species: $180 \mathrm{bp}$ for M. edulis, $126 \mathrm{bp}$ for M. galloprovincialis and 168 bp for M. trossulus (Inoue et al., 1995; Coghlan and Gosling, 2007; Gosling et al., 2008). Fifteen adult mussels per stock as well as 15 individual spat per spawn were analyzed to determine the genotype. For each individual, a gill tissue biopsy stored in $70 \%$ ethanol was used for DNA extraction using the Chelex-based method described by Yue and Orban (2005). Briefly, a small (approximately $30 \mathrm{mg}$ ) piece of gill from each mussel was incubated overnight at $56^{\circ} \mathrm{C}$ in $195 \mu \mathrm{L}$ of $5 \%$ Chelex 100 Resin (Biorad) solution containing $50 \mathrm{mM}$ of Tris-HCL (pH 7) and $500 \mu \mathrm{g} / \mathrm{mL}$ of proteinase $\mathrm{K}$. The samples were then incubated at $95^{\circ} \mathrm{C}$ for $10 \mathrm{~min}$ before being centrifuged at $3500 \mathrm{~g}$ for $5 \mathrm{~min}$. The supernatants were then recovered and frozen at $-20^{\circ} \mathrm{C}$ until use. PCRs were conducted using the Qiagen multiplex PCR kit (Qiagen) in a 10$\mu \mathrm{L}$ volume containing $3 \mu \mathrm{L}$ of genomic DNA diluted to $10 \mathrm{ng} / \mu \mathrm{L}, 5 \mu \mathrm{L}$ of Qiagen PCR Master Mix, $1 \mu \mathrm{L}$ of Qiagen Q-solution, $1 \mu \mathrm{L}$ of Me-16 reverse and 5'-FAM end-labeled Me-15 forward primer mix at $5 \mu \mathrm{M}$ each (Inoue et al, 1995). Amplifications were carried out in a GeneAmp PCR System 2700 thermal cycler (Applied Biosystems) according to the supplier's instructions (Qiagen multiplex PCR kit): initial denaturation step at $95{ }^{\circ} \mathrm{C}$ for $15 \mathrm{~min}$; followed 
by 35 cycles of denaturation at $94{ }^{\circ} \mathrm{C}(30 \mathrm{~s})$, annealing $\left(60{ }^{\circ} \mathrm{C}, 90 \mathrm{~s}\right)$ and extension $\left(72{ }^{\circ} \mathrm{C}, 60\right.$ s); with a final extension step at $60{ }^{\circ} \mathrm{C}$ for $30 \mathrm{~min}$. Amplified PCR fragments were then diluted and separated on an ABIPRISM 3130xl sequencer (Applied Biosystems) with GeneScan 500 Rox dye size standards. Allele size was determined using GeneMapper v4.1 software system (Applied Biosystems, Life Technologies).

\subsection{Trial 1: Mortality survey using a cohabitation protocol within and between the two wild stocks of $M$. edulis}

This experiment tested the potential horizontal transmission of one or more putative mortalitycausing agents between the two wild stocks of $M$. edulis under laboratory conditions. Mussels were placed in $150 \mathrm{~L}$ flow-through tanks with a renewal rate of $250 \mathrm{~L}$ per hour of unheated and UV-filtered seawater. Two conditions were tested: separate versus common (Figure 1). In the separate condition, each stock was reared alone. In the common condition, the two stocks were reared together in the same tank. In the separate condition, the Agnas stock was tested in triplicate with 200 mussels per tank, whereas the Yves stock was tested in duplicate with 200 mussels per tank. The common condition consisted of three tanks each containing 200 mussels of the Agnas stock and 200 mussels of the Yves stock. The experiment was conducted from January to November 2015. Each week, the tanks were emptied and cleaned, and mortality counts were performed every week. Seawater temperature was recorded hourly using two probes (Progesplus, 59780 Willems, France).

2.5. Trial 2: Mortality survey using a cohabitation protocol between adult mussels from the two wild stocks of $M$. edulis and hatchery-produced spat mussels 
Similar to trial 1, individuals from the two stocks of wild mussels of M. edulis were placed in a common tank using 800 mussels from the Agnas stock and 200 mussels from the Yves stock in January 2015 (Figure 2). Mussels were placed in 150 L flow-through tanks with a renewal rate of $100 \mathrm{~L}$ per hour of unheated and UV-filtered seawater. Then, the parents used to produce the G0 crosses for both stocks were transferred into this tank on May $13^{\text {th }} 2015$, consisting of 300 mussels from the Agnas stock and 160 mussels from the Yves stock (Figure 2). Finally, their progenies produced on March 2015 and the progenies from the GG, EE, EG and GE crosses were transferred together into this tank on June $3^{\text {rd }} 2015$ at a comparable biomass of 10 g of spat per group, which corresponded to approximately 250 spat per group; this represented the common condition (Figure 2). For the separate condition, six groups of spat (G0 Agnas, G0 Yves, EE, GG, EG and GE) were each reared separately under the same zootechnical conditions as described above with the exception that 3000 spat per tank. Each week, mortality counts were performed when the tanks were rinsed with freshwater. This experiment was conducted until November 2015.

\subsection{Disease analysis}

Only moribund mussels were analyzed. If they were infected by a pathogen causing the death, $100 \%$ prevalence could be detected with only one individual sampled (Gregory and Blackburn, 1991; Jovani and Tella, 2006).

Five adult mussels $M$. edulis from trial 1 and five adult mussels $M$. edulis from trial 2 were sampled during the main peak of mortality observed in April 2015 along with twenty spat from trial 2 in August 2015 and were analyzed by LGPMM. Each mussel was individually analyzed by histology to detect potential pathogen agents including the notifiable agents Perkinsus sp., Bonamia sp., Marteilia sp., and Mikrocytos sp. After $48 \mathrm{~h}$ of fixation in Davidson's fixative, 
tissues were maintained in $70 \%$ ethanol until their dehydration and then embedded in paraffin for histology according to standard procedures. Paraffin blocks were cut in $2-3-\mu \mathrm{m}$ sections and stained by hematoxylin and eosin.

Bacteria presence was also screened on samples. Five adults sampled in trial 1 in April, 5 adults sampled in trial 2 in April and 5 spat sampled in trial 2 in August were individually analyzed. Pieces of gills, muscle and mantle were crushed in $150 \mu \mathrm{l}$ of sterile seawater; then $100 \mu \mathrm{l}$ of supernatant was diluted 100-fold and 10,000-fold. Each dilution was spread onto Marine agar (Difco) in Petri dishes, which were incubated for $72 \mathrm{~h}$ at $20^{\circ} \mathrm{C}$. Colonies were enumerated and the bacterial colonies found in abundance were sampled and tested by duplex PCR for the detection of Splendidus clade bacteria and Vibrio aestuarianus following the protocol described in Saulnier et al. (2017). Additionally, detection of OsHV-1 was conducted for the adults and 15 spat using the TaqMan real-time PCR protocol as described by Martenot et al. (2010).

In addition to analyses performed during the peak of mortality, 88 moribund mussels were sampled in the different trials from April to September and individually analyzed for the detection of OsHV-1, V. aestuarianus and Splendidus clade bacteria via qPCR. DNA was extracted using the QiagenQiamp® tissue mini kit as described in Schikorski et al. (2011). A final elution of the DNA was performed with $100 \mu \mathrm{L}$ of double-distilled water. The DNA concentration was analyzed spectrophotometrically (NANODROP®) and then adjusted to a final DNA concentration of $4 \mathrm{ng} \mu \mathrm{l}^{-1}$. The detection and quantification of OsHV-1 DNA were performed with the SYBR® Green real-time PCR protocol described by Pépin et al. (2008) as adapted for use with DPFor/DPRev primers (Webb et al. 2007). A qPCR protocol for the detection of Splendidus clade bacteria and V. aestuarianus was conducted following Saulnier et al. (2009 \& 2017). The results were expressed as the bacterial or viral DNA copy number per mg of fresh tissue. 


\subsection{Statistical analysis}

The final cumulative mortality was analyzed by binomial logistic regression as implemented by the Genmod procedure in SAS® 9.4 software.

In trial 1, using the two wild stocks of adult M. edulis, the following model was used:

$\operatorname{Logit}(\mathrm{Y} i j)=\log (\mathrm{Y} i j /(1-\mathrm{Y} i j))=\mu+\operatorname{condition} i+\operatorname{stock} j+\operatorname{condition} i \mathrm{x}$ stock $j$

Where Yij is the probability of mussel death in the $i$ th condition (separate and common) for the $j$ th stock (wild Agnas and wild Yves), and $\mu$ is the intercept. When a significant interaction was observed, the SLICE option was used. This approach allowed for a more powerful analysis than provided by rerunning the model for each effect because the degrees of freedom are not reduced (Littell, et al., 2002).

In trial 2, the mortality for the mixed condition was analyzed using the following model:

$\operatorname{Logit}(\mathrm{Y} i)=\mu+\operatorname{stock} i$

Where $Y i$ is the probability of mussel death in the $i$ th stock. Four comparisons were analysed: (1) wild Agnas versus wild Yves, (2) wild Agnas parents versus wild Yves parents, (3) G0 Agnas versus G0 Yves, and (4) EE, EG, GE and GG for which multiple comparison tests were conducted using the least squares means statement and the PDIFF option. 


\section{Results}

\subsection{Species identification}

Using the two primers Me 15 and Me 16, which were designed to amplify a non-repetitive region of the adhesive gene (Glu), PCR analysis indicated that all individuals of the parental species exhibited only a single band, which was $176 \mathrm{bp}$ in length for M. edulis and $120 \mathrm{bp}$ for M. galloprovincialis. All of the individuals from the interspecific crosses produced both of the 120- and 176 bp bands (Figure 3). Interestingly, only bands corresponding to M. edulis and/or to M. galloprovincialis were detected, and no band corresponding to another blue mussel (e.g., M. trossulus) was evidenced.

\subsection{Seawater temperature}

The seawater temperature recorded in our laboratory during trials in 2015 is shown in Figure 4. The temperature ranged from 6 to $10^{\circ} \mathrm{C}$ in January and increased to $12^{\circ} \mathrm{C}$ in February. From March to July 2015, the seawater temperature progressively increased from 12 to $23^{\circ} \mathrm{C}$; it then decreased throughout the remainder of the experiment to $16^{\circ} \mathrm{C}$ in November.

\subsection{Trial 1: Mortality survey using a cohabitation protocol within and between the two wild stocks of $M$. edulis}

In the separate condition, the Agnas stock exhibited low mortality throughout the trial, reaching $5.8 \%$ mortality in November 2015 . In contrast, moderate mortality $(32.0 \%$ at the end of the trial) was observed for the Yves stock, which began during the first week of March and occurred until the end of the trial (Figure 5A). A similar pattern of mortality was observed for the Yves stock in the mixed condition, with a cumulative final mortality of $29.7 \%$ (Figure 5B). In contrast 
to the Agnas stock in the separate condition, the Agnas stock in the mixed conditioned experienced high mortality, mostly occurring between April and July and reaching $45.8 \%$ in November 2015 (Figure 5B). A significant interaction was found between stock and condition $(\mathrm{p}<0.0001)$. Mortality was significantly higher for the Agnas stock than for the Yves stock in the mixed condition, whereas the opposite pattern occurred in the separated condition $(\mathrm{p}<0.0001)$. The Agnas stock exhibited significantly higher mortality in the mixed condition than in the separate condition $(\mathrm{p}<0.0001)$, whereas the Yves stock had similar mortality in both conditions $(\mathrm{p}=0.70)$.

\subsection{Trial 2: Mortality survey using a cohabitation protocol between spat and adult mussels}

For adults tested under the common condition, no abnormal mortality was observed for the Agnas and Yves stocks from January to mid-April 2015. Starting from the last week of April, a massive mortality outbreak was observed for both stocks, which reached $75 \%$ in May and $94 \%$ in June. In November, mortality was not significantly different between the two stocks, with 99.2 and 99.4\% mortality for Agnas and Yves, respectively ( $\mathrm{p}=0.86)$ (Figure 6A).

For the individuals from these same stocks that were used as parents for the G0 crosses and placed into the tank on May $13^{\text {th }}$, the mortality began the following week and lasted for three months. Mortality reached $81.6 \%$ for the Agnas stock by the end of August (Figure 6A). In contrast, the mortality pattern was different for the Yves stock. The cumulative mortality remained low in May (8.1\%) and June (10.8\%), then increased to $22.9 \%$ at the end of July. A sharp increase in mortality occurred in August, particularly from August $18^{\text {th }}$ to August $31^{\text {st }}$, with mortality reaching $56.1 \%$ (Figure 6A). The parents of both stocks continued to exhibit low 
mortality until the end of the experiment in November, with mortality reaching $88.9 \%$ for the Agnas stock; the Yves stock had significant lower mortality, at 62.4\% (p<0.0001).

For spat tested in the mixed condition with adults, the onset of the mortality was one week after their transfer into the tank for the G0 Yves and one month after their transfer into the tank for all of the other groups (G0 Agnas, EE, GG, EG and GE) (Figure 6B). Although regular mortality was observed for the G0 Yves group throughout the experiment, a sharp increase in mortality from 13.1 to $61.6 \%$ was observed during the last two weeks of August for G0 Agnas. In November, the final mortality was significantly higher $(\mathrm{p}<0.0001)$ for G0 Agnas $(68.1 \%)$ than G0 Yves (26.8\%). For all of the EE, GG, EG and GE spat groups, the first dead mussels were reported one month after establishment of the four stocks, but mortality remained low $(<7 \%)$ until August $18^{\text {th }}$ (Figure 6B). Then, a moderate mortality event occurred during the last two weeks of August, which was more severe for the two hybrid stocks. In November, the GG and EE stocks exhibited the lowest mortality, with 15.8 and $19.9 \%$, respectively, which did not statistically differ between the two groups $(p=0.18)$. Significantly higher mortality was observed for the two hybrid stocks ( $\mathrm{p}<0.01$ ), which was similar between the GE and EG groups $(\mathrm{p}=0.86)$, at 29.7 and $30.5 \%$ mortality, respectively.

For spat tested in the separate condition, no mortality was observed except in one tank of G0 Agnas stock located near the tank of the mixed condition. The mortality occurred during the two last weeks of August, reaching $63.7 \%$ by August $31^{\text {st }}$ and $65.0 \%$ in November.

\subsection{Disease analysis}

Histological analyses revealed the absence of protozoan and metazoan parasites including the parasite Marteilia refringens. Only few ciliates were noted on 3 individuals of the trial 1 . No hemocytic infiltration was noted but severe necrosis of connective tissues of gills, mantle, labial 
palps and digestive gland were observed. Posterior adductor muscle also presented a severe necrosis of myocytes. No lesion as inclusion body or nuclear abnormality suggesting potential viral infection was noted.

Neither OsHV-1 nor Vibrio aestuarianus were detected from the moribund mussels sampled in trials 1 and 2 (Table 2). In contrast, high amount of DNA of bacteria belonging to Splendidus clade (in average $>10^{+7}$ copies per $\mathrm{mg}$ of mussel tissue) were detected in both trials, and the detection frequency was high, ranging from 75 to 100\% except in August. In August, only 3 of 24 moribund mussels analyzed (19 adults and 5 spat) were positive for Splendidus clade bacteria. Nevertheless, other bacteria were detected on petri dishes for each mussel screened in August (Table 2). 


\section{Discussion}

In the context of mass mortality outbreaks affecting adult and juvenile mussels since 2014 in France and to investigate the impact of genetic background of mussel stocks, particularly in relation to their life history and interspecific variability, we used pure and hybrid crosses involving different stocks of the two commercially important blue mussels farmed in France, M. edulis and M. galloprovincialis. This experiment was not set up to identify the putative causal agent or prove the etiology of mussel mortality, but showed preliminary investigations to describe mortality outbreaks at two life-stages (spat and adult) for the two main mussel species grown in France.

\subsection{Mortality investigation of M. edulis in adults}

\subsubsection{Trial 1}

The main result of this study revealed different mortality kinetics in trial 1 using a cohabitation protocol within and between the two wild stocks of M. edulis.

Thus, the Yves stock, which experienced a mortality outbreak in open field conditions in 2014 (Robert et al., 2015), still exhibited 32.0 and 29.7\% mortality during 2015 for the separated and mixed conditions, respectively (Figure 5) whereas the density were different between the two conditions. In contrast, the Agnas stock, which settled in 2014 on our aquaculture gears from our oyster farm located at this site, did not exhibit abnormal mortality in 2014 (data not shown) and showed low mortality in $2015(5.8 \%)$ in trial 1 when it was maintained separately in the tanks (Figure 5A). This suggests that survivors of the Yves stock could have been carriers of a putative causal agent of mortality and that mussels of the Agnas stock should be free of this putative causal agent. In addition, survivors of a mortality outbreak in field condition are not fully genetically resistant to this putative causal agent if mortality in field and laboratory 
conditions had the same etiology. This interpretation is in agreement with results observed for successive exposures to Vibrio strains reported in C. gigas (Azéma, et al., 2015) and Haliotis tuberculata (Travers, et al., 2010).

In contrast to the separate condition in trial 1, moderate mortality (45.8\%) was observed for the Agnas stock when it was in contact with the Yves stock (Figure 5B). This finding suggests a possible horizontal transmission of a putative causal agent from the Yves stock to the Agnas stock. This is in agreement with the experimental demonstration of horizontal transmission between asymptomatic carriers of OsHV-1 from wild-caught spat to naïve hatchery-produced spat in Crassostrea gigas using separated and mixed conditions (Dégremont and Benabdelmouna, 2014). In addition, the higher mortality reported for the mussels of the Agnas stock than mussels of the Yves stock in the mixed condition suggested a higher susceptibility to the putative causal agent for the Agnas stock and/or a higher resistance of the Yves stock which already experienced a mortality outbreak in the field in 2014. Thus, difference in susceptibility to the mortality outbreaks reported in mussels on the Atlantic coast since 2014 could be explained by the life-history of each stock or their genetic resistance to the putative causes of the mortality. Nevertheless, further investigations are required to know the genetic basis of resistance to mortality outbreak in mussels.

At present, it is not possible to affirm that a putative pathogen is responsible for this mortality. The disease screening revealed the absence of OsHV-1, Vibrio aestuarianus and parasites among the moribund mussels analyzed (Table 2). Although bacteria belonging to the Splendidus clade were detected, it is unclear whether they were the causal agent of the mortality. Indeed, the Spendidus clade is composed of 17 different bacteria species (Sawabe et al. 2013, Poli et al. 2018) among which some of them are part of normal flora of mussels in hatchery whatever the mussel stage (Kwan and Bolch 2015). A recent study demonstrated that strain belonging to the species Vibrio splendidus, that was isolated from moribund mussels was able 
to induce significant mortality in $M$. edulis following experimental infection under laboratory conditions (Ben Cheikh, et al., 2015). Similar experimental infection was conducted using 23 Vibrio strains isolated from moribund mussel batches collected in Charente-Maritime and in Normandy in June 2014, and some of them induced high mortality in healthy adult mussels Mytilus sp. (Oden et al., 2016). In any cases, such demonstration cannot validate that the Splendidus clade bacteria isolated in our study are the causal agent of the mortality observed in our trial and in French mussel farms. A striking example exists in $C$. gigas for which $V$. splendidus-related strains isolated from moribund oysters sampled during mortality outbreaks induced mortality under experimental infections (Gay, et al., 2004; Lacoste, et al., 2001). However, resistant and susceptible lines of $C$. gigas selected for their survival during summer mortality outbreak in field condition, which were later identified as resistant to OsHV-1 infection (Dégremont, 2011), both showed high mortality and did not exhibit contrasted mortality under experimental injection of virulent $V$. splendidus strains in laboratory (Gay, 2004; Huvet, et al., 2007). Thus, if some $V$. splendidus related strains can induce mortality in C. gigas in laboratory, it was not the main cause of mortality observed in the field; this may also be true for M. edulis. Further characterizations of isolated bacteria are needed to know more precisely the bacteria species and especially their virulence.

\subsubsection{Trial 2}

In trial 2, both wild stocks (Agnas and Yves) experienced rapid and intense mortality in April and May 2015 (Figure 6A). This result contrasted with the mortality pattern in the mixed condition in trial 1, in which mortality lasted from March to November 2015 (Figure 5B). Although no replicates were used our results suggest that this difference in mortality pattern could be explained by the higher mussel density used in trial 2, with 400 mussels per tank in 
trial 1 and 1000 mussels in trial 2, combined with a lower water renewal, $250 \mathrm{~L}$ per hour in trial 1 and $100 \mathrm{~L}$ per hour in trial 2. Such differences in mortality with condition has been clearly demonstrated in $C$. gigas, with the odds of disease mortality decreasing with increasing water renewal and increasing with the biomass of neighboring infected oysters under controlled conditions (Petton, et al., 2015). Another hypothesis could rely on the difference in temperature between both trials. The putative causal agent could induce higher mortality when temperature is around $15^{\circ} \mathrm{C}$ (trial 2) than at $12^{\circ} \mathrm{C}$ (trial 1) (Figure 4) as observed at the larval stage in $M$. edulis and M. trossulus (Yound and McCartney, 2016). In combination, when mortality was triggered at $12^{\circ} \mathrm{C}$, the mussels could have been immune-primed with the putative causal agent with a consequence to reduce the mortality, as demonstrated in oysters (Green and Montagnani, 2013), while there were not when the onset of the mortality occurred at $15^{\circ} \mathrm{C}$. The last hypothesis concerns a spawning event that could have occurred at the end of April for adult mussels in trial 2. For the individuals analyzed in histology, most of them (80\%) presented a gonad in regression indicating that the most of the mussels spawn. Spawning is an important factor on the susceptibility to stress in bivalves. The energy expended during reproduction compromises the immune status of oysters, leaving them easily subject to mortality if a stress occurs in postspawning stage, such heat stress (Li et al., 2007) or pathogens, including OsHV1 (Dégremont et al., 2013) and Vibrio sp. (Wendling and Wegner, 2013).

The transfer of parents of the G0 Agnas and G0 Yves into the tank where massive mortality was occurring for both wild stocks indicated that horizontal transmission of a putative mortality causative agent, if present, was rapid, as the mortality started one week post transfer (Figure 6A). Furthermore, the mortality pattern of the parents was lower than that of their counterparts not used as parents. This difference could be explained by a decrease of the infectious source due to the important mortality of wild stock individuals; indeed, in cohabitation challenge, the number of added cohabitants could influence the mortality rate as shown for Aeromonas 
salmonicida in Atlantic salmon (Nordmo and Ramstad 1999). Another explanation is the different reproductive status between these types, as the parents were induced to spawn in March 2015 when the others were ripe (data not shown). This interpretation is in agreement with findings in oysters that highlight the importance of sexual maturity in vibriosis infection processes (De Decker, et al., 2011). A third explanation relies on the seawater temperature, which was around $19^{\circ} \mathrm{C}$. It could be possible that the putative causal agent could still kill the mussels but at a slower rate than at $15^{\circ} \mathrm{C}$.

At the end of July, mortality of the mussels which were used as parents of the G0-Agnas had $65 \%$ of mortality while it was $23 \%$ for the parents of the G0-Yves (Figure 6A). Although no replicates were used for the common condition in trial 2 , this is similar to the final mortality observed in the mixed condition in trial 1 . Genetic resistance and/or life-history could explain this difference as explained in trial 1.

Disease screening in trial 2 had similar findings than trial 1 with the absence of detection of OsHV-1, V. aestuarianus, Perkinsus sp, Bonamia sp, Marteilia sp, and Mikrocytos sp, while prevalence of bacteria of Splendidus clade was high with high amount of DNA (in average $>10^{+7}$ copies per mg of tissue). Nevertheless, second mortality outbreaks occurred in adults in August, especially for the mussels used as parents of the G0-Yves (Figure 6A), while the seawater temperature was $22^{\circ} \mathrm{C}$ (Figure 4). Disease screening revealed a drop of the prevalence of bacteria of Splendidus clade in August (30\%), as well as a drop of the DNA amount although it remained high (in average $>10^{+5}$ copies per mg of mussel tissue). Then, it is possible that another putative causal agent triggered this summer mortality in $M$. edulis which were asymptomatic carriers. This is in agreement with finding obtained by Eggermont et al. (2017) who reported that wild mussels contain a reservoir of 17 pathogenic bacteria. 


\subsection{Mortality investigation in hatchery-produced spat of $M$. edulis, $M$. galloprovincialis and their hybrids in trial 2}

Low mortality $(<10 \%)$ was observed for all spat batches (G0-Agnas, G0-Yves, EE, GG, EG and GE) during their first month in the tank of the mixed condition and it remained below $20 \%$ for three months post-transfer (Figure 6B). This suggests the horizontal transmission of a putative causal agent from wild adults to naïve hatchery-produced spat. These findings are in agreement with the horizontal transmission of OsHV-1 from asymptomatic adults that were infected in the field to hatchery-produced naïve spat in $C$. gigas under controlled laboratory conditions (Dégremont, et al., 2013).

From May to July, spat had lower mortality than adult in the mixed condition (Figure 6A \& B). One of the possible explanations of this lower mortality is that, in Mytilus edulis, spat could be less susceptible to the putative causal agent of the mortality than adults. Similar difference in susceptibility to pathogen between spat and adults was demonstrated by experimental infection with V. aestuarianus and OsHV-1 in naïve C. gigas (Azéma, et al., 2017). Although no replicates were used, our results suggest that such observation seems to be also valid in Mytilus edulis.

The G0 Agnas stock exhibited a significant mortality event in the mixed condition in August (68\%); as reported for adults tested in the same tank (Figure 6). For the separated condition, only the tank adjacent to the tank of the mixed condition, which contained only G0 Agnas, had mortality at the same time and to the same degree $(65 \%)$. We postulate that there was an uncontrolled contamination of this tank from the mixed condition tank during the mortality count and/or cleaning. Disease diagnosis in August revealed negative results for all pathogens tested, even for the Splendidus clade (Table 2). The same trend was observed for adults in trials 1 and 2. In contrast, other bacteria were cultivated on petri dished (Table 2) which will be 
sequenced to know their classification. Although additional studies should be realized, the decrease of detection of Splendidus clade bacteria during the peak of the mortality outbreak in August was surprising and does not support the hypothesis that bacteria belonging to this clade were the putative causal agent of the mortality observed during this period.

At the intraspecific level in M. edulis, the mortality of the spat group G0 Agnas, which was produced using naïve progenitors that did not experience mortality in 2014, was significantly higher (68\%) than those of G0 Yves (27\%) and EE (20\%), which were both produced from survivors of a mortality outbreak in 2014. Although no replicates were used, the difference in mortality between G0 Yves/EE and G0 Agnas suggest difference in resistance to this mortality event in spat $M$. edulis. Such difference in survival among families was also reported in $M$. edulis and M. trossulus at the larval stage (Yund and McCartney, 2016). This result suggests that selection for improved resistance to mortality outbreaks could be possible.

At the interspecific level, when comparing spat produced from naïve progenitors, i.e., $M$. galloprovincialis and wild M. edulis from Agnas, which did not undergo mortality outbreaks during 2014, the final mortality exhibited by their respective offspring, GG and G0 Agnas, differed. Although no replicates were used, the significantly lower mortality exhibited by GG spat (16\%) compared with that of G0 Agnas spat (68\%) likely indicates a natural resistance/tolerance of $M$. galloprovincialis against the putative causing agent of the mortality observed in August. Similar finding showed that the mussel Mytilus galloprovincialis seemed very resistant to bacterial infection (Romero et al., 2014). Such natural resistance of $M$. galloprovincialis was already observed by Fuentes et al. (2002), who found that both Galician and Mediterranean M. galloprovincialis exhibited much lower mortality compared with both M. edulis and their respective hybrids. The same authors suggested that strong viability selection was operating against hybrid mussels relative to pure M. galloprovincialis crosses, which was also described in natural populations of the M. edulis/M. galloprovincialis hybrid 
zone in SW England (Gardner et al., 1993; Wilhelm and Hilbish, 1998). Interestingly, the $M$. edulis progenitors used in Fuentes et al. (2002) were likely of poor quality, as the M. edulis pure crosses were unsuccessful, whereas M. edulis x $M$. galloprovincialis showed an abnormally high (50\%) prevalence of disseminated neoplasia that normally occurs in Galician mussel populations at a very low prevalence (<1\%, Figueras et al., 1991; Villalba et al., 1997). In our present study, the case of disseminated neoplasia, as a potential direct or indirect causative agent of the mortality, could not be excluded as genomic abnormalities with distinctive features of disseminated neoplasia were recently found in blue mussels from various French areas (Benabdelouna and Ledu 2016). In this study, these initial genomic abnormalities intensities were shown to be significantly correlated to the final mortality levels of blue mussels in France. Finally, this disease present additional features that advocate for its possible implication in the observed mortality outbreaks as it could be horizontally transmitted from neoplastic individuals to healthy ones in other mollusc species, and as it affect more preferably adult than spat and juveniles (Elston et al. 1988, Barber 2004, Carballal et al. 2015). However, as the initial cytogenetic and hemocytologic status of the mussels tested in this work was not determined, the real implication of disseminated neoplasia disease as the causative agent of the observed mortality outbreaks is still hypothetical. Moreover, the few histological analyses performed did not revealed the presence of hemocyte neoplasia.

In contrast to the above-mentioned studies, the EG and GE hybrid crosses tested in our present work showed relatively good survival ability, exhibiting lower mortality (30\%) than did the $M$. edulis G0 Agnas stock (68\%). Compared with previous works that described mortality in natural (Gardner et al., 1993; Wilhelm and Hilbish, 1998) or hatchery-produced populations (Fuentes et al., 2002), a possible explanation for the high survival of hybrid groups in our study involves our production of the different spat groups, in which M. edulis progenitors were carefully chosen from stocks that survived the heavy mortality outbreaks during 2014. 
Consequently, the previously described strong viability selection operating against hybrid mussels might have been compensated for by the use of selected M. edulis progenitors.

\section{Conclusions}

In the present work, we described several mortality outbreaks affecting spat and adult mussels. This is a preliminary investigation in the context of the massive mortality outbreaks recently reported in France since 2014 and further experiments are required to evaluate the susceptibility of M. edulis and M. galloprovincialis at different life-stages and to identify the causal agents of the mortality. We demonstrated the horizontal transmission of one or several putative causal agents of mortality in M. edulis under laboratory conditions in 2015 from the survivors of a 2014 mortality outbreak to another stock of wild adults. Such transmission was also observed from wild adults to their hatchery-produced progenies. Although no replicates were used, our results suggest that $M$. edulis could be more susceptible to mortality than $M$. galloprovincialis at the spat stage. The exploration of both intraspecific and interspecific genetic variability could help in establishing new mussels stocks that are resistant/tolerant to causal agent of the current mortality outbreaks, but further data are needed on the other life stages. Similarly, the progenies of survivors of mortality outbreaks were more resistant than the progenies produced from stocks that did not experience such mortality. Thus, there is potential for breeding programs to provide improved strains and thereby reduce the impact of mortality in mussel aquaculture. Finally, our study was unable to identify the putative causal agent of the mortality observed in the laboratory although Splendidus clade bacteria was detected throughout the study except in August. To identify potential pathogens, more diagnosis analyses should be performed and stocks that showed variation in susceptibility should be tested in mussel aquaculture farms and undergo experimental infections to compare their resistance level in both environments. 


\section{Acknowledgements:}

The authors are grateful to the LGPMM hatchery staff for technical assistance in the hatchery. We thank the pathology staff, who conducted some of the disease analyses. We also acknowledge Florence Rivet for her help with bibliographic research as well as Benjamin Morga for drawing some of the figures reported in this manuscript. This work was funded by Ifremer's research actions (Amélioration par les modifications de ploïdie, A070212F and Amélioration par la sélection, A070212E), as well as by DGAL through the National Reference Laboratory for Mollusc Diseases. 


\section{References}

Azéma, P., Travers, M.A., De Lorgeril, J., Tourbiez, D., Dégremont, L., 2015. Can selection for resistance to OsHV-1 infection modify susceptibility to Vibrio aestuarianus infection in Crassostrea gigas? First insights from experimental challenges using primary and successive exposures. Vet. Res. 46, 139.

Azéma, P., Maurouard, E., Lamy, J.B., Dégremont, L., 2017. The use of size and growing height to improve Crassostrea gigas farming and breeding techniques against OsHV-1. Aquaculture 471, 121-129.

Barber, B., 2004. Neoplastic diseases of commercially important marine bivalves. Aquat. Living Resour. $17,449-466$.

Béchemin, C., Soletchnik, P., Polsenaere, P., Le Moine, O., Pernet, F., Protat, M., Fuhrman, M., Quéré, C., Goulitquer, S., Corporeau, C., Lapègue, S., Travers, A., Morga, B., Garrigues, M., Garcia, C., Haffner, P., Dubreuil, C., Faury, N., Baillon, L., Baud, J-P., Renault. T., 2015. Episodes de mortalité massive de moules bleues observés en 2014 dans les Pertuis charentais. Bull. Epidémiol. Hebd. 67 : 6-9.

Benabdelmouna, A., Ledu, C., 2016. The mass mortality of blue mussels (Mytilus spp.) from the Atlantic coast of France is associated with heavy genomic abnormalities as evidenced by flow cytometry. J. Invertebr. Pathol. 138, 30-38.

Ben Cheikh, Y., Travers, M.A., Morga, B., Godfrin, Y., Rioult, D., Le Foll, F., 2015. First evidence for a Vibrio strain pathogenic to Mytilus edulis altering hemocyte immune capacities. Dev. Comp. Immunol. 57, 107-119.

Bierne, N., Borsa, P., Daguin, C., Jollivet, D., Viard, F., Bonhomme, F., David, P., 2003. Introgression patterns in the mosaic hybrid zone between Mytilus edulis and M. galloprovincialis. Mol. Ecol. $12,447-461$.

Carballal, M.J., Barber, B.J., Iglesias, D., Villalba, A., 2015. Neoplastic diseases of marine bivalves. J. Invertebr. Pathol. 131: 83-106.

Coghlan, B., Gosling, E., 2007. Genetic structure of hybrid mussel populations in the west of Ireland: two hypotheses revisited. Mar. Biol. 150, 841-852

Daguin, C., Bonhomme, F. \& Borsa, P., 2001. The zone of sympatry and hybridization of Mytilus edulis and M. galloprovincialis, as described by intron length polymorphism at locus mac-1. Heredity 86, 342-354. 
De Decker, S., Normand, J., Saulnier, D., Pernet, F., Castagnet, S., Boudry, P., 2011. Responses of diploid and triploid Pacific oysters Crassostrea gigas to Vibrio infection in relation to their reproductive status. J. Invertebr. Pathol. 106, 179-191.

Dégremont, L., 2011. Evidence of herpesvirus (OsHV-1) resistance in juvenile Crassostrea gigas selected for high resistance to the summer mortality phenomenon. Aquaculture 317, 94-98.

Dégremont, L., Benabdelmouna, A., 2014. Mortality associated with OsHV-1 in spat Crassostrea gigas: role of wild-caught spat in the horizontal transmission of the disease. Aquacult. Int. 22, 17671781.

Dégremont, L., Guyader, T., Tourbiez, D., Pépin, J.-F., 2013. Is horizontal transmission of the Ostreid herpesvirus OsHV-1 in Crassostrea gigas affected by unselected or selected survival status in adults to juveniles? Aquaculture 408-409, 51-57.

Eggermont, M., Bossier, P., Pande, G.S.J., Delahaut, V., Rayhan, A.M., Gupta, N., Islam, S.S., Yumo, E., Nevejan, N., Sorgeloos, P., Gomez-Gil, B., Defoirdt, T., 2017. Isolation of Vibrionaceae from wild blue mussel (Mytilus edulis) adults and their impact on blue mussel larviculture. FEMS Microbiol. Ecol. 93, fix39.

Elston, R.A., Kent, M.L., Drum, A.S., 1988. Transmission of hemic neoplasia in the bay mussel, Mytilus edulis, using whole cells and cell homogenate. Dev. Comp. Immunol. 12: 719-727.

FAO, 2017. Fisheries and aquaculture software. FishStatJ - software for fishery statistical time series. FAO Fisheries and Aquaculture Department Rome. http://www.fao.org/fishery/statistics/software/fishstatj/en.

Figueras, A.J., Jardo'n, C.F., Caldas, J.R., 1991. Diseases and parasites of rafted mussels (Mytilus galloprovincialis Lmk): preliminary results. Aquaculture 99, 17-33.

Fuentes, J., Lopez, J. L., Mosquera, E., Vazques, J., Villalba, A., Alvarez, G., 2002. Growth, mortality, pathological conditions and protein expression of Mytilus edulis and M. galloprovincialis crosses cultured in the Ria de Arousa (NWSpain). Aquaculture 213, 233-251.

Fuentes, J., Reyero, I., Zapata, C., Alvarez, G., 1992. Influence of stock and culture site on growth rate and mortality of mussels (Mytilus galloprovincialis Lmk.) in Galicia, Spain. Aquaculture 105, 131-142.

Fuentes, J., Reyero, I., Zapata, C., Alvarez, G., 1994. Production traits of the mussel Mytilus galloprovincialis cultured in Galicia (NW of Spain): relative effects of source of seed and growing environment. Aquaculture 122, 19-31. 
Gardner, J.P.A., Skibinski, D.O.F., Bajdik, C.D., 1993. Shell growth and viability differences between the marine mussels Mytilus edulis (L.), Mytilus galloprovincialis (Lmk.), and their hybrids from two sympatric populations in S.W. England. Biol. Bull. 185, 405- 416.

Gay, M., Renault, T., Pons, A.M., Le Roux, F., 2004. Two Vibrio splendidus related strains collaborate to kill Crassostrea gigas: taxonomy and host alterations. Dis. Aquat. Org. 62, 65-74.

Gay, M., 2004. Infection expérimentale chez Crassostrea gigas : étude de deux souches pathogènes apparentées à Vibrio splendidus. PhD Thesis, Université de La Rochelle.

Gosling, E., Doherty, S., Was, A. 2008. Genetic characterization of hybrid mussel (Mytilus) populations on Irish coasts. J. Mar. Biol. Assoc. U.K. 88: 341-346

Gosling, E.M., 1992. Systematics and geographical distribution of Mytilus. In: The mussel Mytilus: ecology, physiology, genetics and culture (E. M. Gosling, ed.) Elsevier, Amsterdam, pp. 1-20.

Goulletquer, P., Héral, M., 1997. Marine molluscan production trends in France: from fisheries to aquaculture. In: NOAA Technical report NMFS 129, pp. 137-164.

Green, T.J., Montagnani, C., 2013. Poly I:C induces a protective antiviral immune response in the Pacific oyster (Crassostrea gigas) against subsequent challenge with Ostreid herpesvirus (OsHV-1 mu var). Fish Shellfish Immunol. 35, 382-388.

Gregory, R.D., Blackburn, T.M., 1991. Parasite prevalence and host sample size. Parasitol. Today. 7, 316-318.

Hilbish, T.J., Carson, E.W., Plante, J.R., Weaver, L.A. \& Gilg, M.R., 2002. Distribution of Mytilus edulis, M. galloprovincialis, and their hybrids in open-coast populations of mussels in southwestern England. Mar. Biol. 140: 137-142.

Huvet, A., Royer, J., Moal, J., Burgeot, T., Lapègue, S., Boulo, V., Nicolas, J.L., Lambert, C., Van Wormhoudt, A., Samain, J.F., 2007. Phenotypic characteristics of 'R' and 'S' oyster lines, selected for resistance or susceptibility to summer mortality. In: Samain, J.F., McCombie, H. (Eds.), Summer mortality of Pacific oyster Crassostrea gigas. The Morest project. Quae Editions, Versailles, pp. 197-241.

Inoue, K., Waite, J.H., Matsuoka, M., Odo, S. \& Harayama, S., 1995. Interspecific variations in adhesive protein sequences of Mytilus edulis, M. galloprovincialis, and M. trossulus. Biol. Bull. 189: 370375.

Jovani, R., Tella, J.L., 2006. Parasite prevalence and sample size: misconceptions and solutions. Trends Parasitol. 22, 214-218.

Kwan TN, Bolch C.J.S. 2015 Genetic diversity of culturable Vibrio in an Australian blue mussel Mytilus galloprovincialis hatchery. Dis Aquat. Org. 116: 37-46. 
Lacoste, A., Jalabert, F., Malham, S., Cueff, A., Gelebart, F., Cordevant, C., Lange, M., Poulet, S.A., 2001. A Vibrio splendidus strain is associated with summer mortality of juvenile oysters Crassostrea gigas in the Bay of Morlaix (North Brittany, France). Dis. Aquat. Org. 46, 139-145.

Li, Y., Qin, J.G., Abbott, C.A., Li, X.X., Benkendorff, K., 2007. Synergistic impacts of heat shock and spawning on the physiology and immune health of Crassostrea gigas: an explanation for summer mortality in Pacific oysters. Am. J. Physiol.- Regul. Integr. Comp. Physiol. 293, R2353R2362.

Littell, R. C., Stroup, W.W., Freund, R.J., 2002. SAS ${ }^{\circledR}$ for Linear Models. SAS Institute Inc., Cary, NC.

Martenot, C., Oden, E., Travaillé, E., Malas, J.P., Houssin, M., 2010. Comparison of two real-time PCR methods for detection of ostreid herpesvirus 1 in the Pacific oyster Crassostrea gigas. J. Virol. Methods 170, 86-89.

Myrand, B, Gaudreault, J., 1995.Summer mortality of blue mussels (Mytilus edulis Linneaus, 1758) in the Magdalen Islands (southern Gulf of St Lawrence, Canada). J. Shellfish Res. 14, 395-404.

Myrand, B., Guderley, H., Himmelman, J., 2000. Reproduction and summer mortality of blue mussels Mytilus edulis in the Magdalen Islands, southern Gulf of St. Lawrence. Mar. Ecol. Prog. Ser. 197, 193-207.

Nordmo, R., Ramstad, A., 1999. Variables affecting the challenge pressure of Aeromonas salmonicida and Vibrio salmonicida in Atlantic salmon (Salmo salar L.). Aquaculture 171: 1-12.

Oden, E., Burioli, E.A.V., Trancart, S., Pitel, P.H., Houssin, M., 2016. Multilocus sequence analysis of Vibrio splendidus related-strains isolated from blue mussel Mytilus sp. during mortality events. Aquaculture 464, 420-427.

Petton, B., Boudry, P., Alunno-Bruscia, M., Pernet, F., 2015. Factors influencing disease-induced mortality of Pacific oysters Crassostrea gigas. Aquacult. Env. Interac. 6, 205-222.

Poli, A., Romano, I., Mastascusa, V., Buono, L., Orlando, P., Nicolaus, B., Leone, L., Hong, K.W., Chan, K.G., Goh, K.M., Pascual, J. 2018. Vibrio coralliirubri sp. nov., a new species isolated from mucus of red coral (Corallium rubrum) collected at Procida island, Italy. Antonie Van Leeuwenhoek.

Polsenaere, P., Soletchnik, P., Le Moine, O., Gohin, F., Robert, S., Pépin, J.-F., Stanisière, J.-Y., Dumas, F., Béchemin, C., Goulletquer, P., 2017. Potential environmental drivers of a regional blue mussel mass mortality event (winter of 2014, Breton Sound, France). J. Sea Res. 123, 39-50.

Robert, S., Bouget, J.-F., Fleury, E., Chauvin, J., Gagnery, A., Normand, J., Blin, J.L., Cheve, J., Dagault, F., Gerla, D., Lejolivet, A., Penot, J., Chabirand, J.M., Genauzeau, S., Geairon, P., Grizon, J., Le Moine, O., Schmitt-Gallotti, A., Seugnet, J.-L., Soletchnik, P., 2015. Réseau national d'observation de la moule bleue Mytilus edulis, MYTILOBS, Campagne 2014-2. 
Romero, A., Costa, M. M., Forn-Cuni, G., Balseiro, P., Chamorro, R., Dios, S., Figueras, A., Novoa, B., 2014. Occurrence, seasonality and infectivity of Vibrio strains in natural populations of mussels Mytilus galloprovincialis. Dis. Aquat. Org. 108, 149-163.

Saulnier, D., De Decker, S., Haffner, P., 2009. Real-time PCR assay for rapid detection and quantification of Vibrio aestuarianus in oyster and seawater: A useful tool for epidemiologic studies. J. Microbiol. Methods 77, 191-197.

Saulnier, D., De Decker, S., Tourbiez, D., Travers, M.A., 2017. Development of a duplex Taqman realtime PCR assay for rapid identification of Vibrio splendidus-related and $V$. aestuarianus strains from bacterial cultures. J. Microbiol. Methods 140, 67-69.

Sawabe, T., Ogura, Y., Matsumura, Y., Feng, G., Amin, A., Mino, S., Nakagawa, S., Sawabe, T., Kumar, R., Fukui, Y., Satomi, M., Matsushima, R., Thompson, F.L., Gomez-Gil, B., Christen, R., Maruyama, F., Kurokawa, K., Hayash T., 2013. Updating the Vibrio clades defined by multilocus sequence phylogeny: proposal of eight new clades, and the description of Vibrio tritonius sp nov. Front Microbiol. 4, 414.

Schikorski, D., Faury, N., Pepin, J.F., Saulnier, D., Tourbiez, D., Renault, T., 2011. Experimental ostreid herpesvirus 1 infection of the Pacific oyster Crassostrea gigas: Kinetics of virus DNA detection by q-PCR in seawater and in oyster samples. Virus Res. 155, 28-34.

Travers, M.A., Meistertzheim, A.L., Cardinaud, M., Friedman, C.S., Huchette, S., Moraga, D., Paillard, C., 2010. Gene expression patterns of abalone, Haliotis tuberculata, during successive infections by the pathogen Vibrio harveyi. J. Invertebr. Pathol. 105, 289-297.

Tremblay, R., Myrand, B., Sevigny, J.M., Guderley, H., 1998. Bioenergetic and genetic parameters in relation to susceptibility of blue mussels, Mytilus edulis (L) to summer mortality. J. Exp. Mar. Biol. Ecol. 221, 27-58.

Villalba, A., Mourelle, S.G., Carballal, M.J., Lo'pez, M.C., 1997. Symbionts and diseases of farmed mussels Mytilus galloprovincialis throughout the culture process in the Rı'as of Galicia (NW Spain). Dis. Aquat. Org. 31, 127-139.

Wendling, C.C., Wegner, K.M., 2013. Relative contribution of reproductive investment, thermal stress and Vibrio infection to summer mortality phenomena in Pacific oysters. Aquaculture 412, 8896.

Wilhelm, R., Hilbish, T.J., 1998. Assessment of natural selection in a hybrid population of mussels: evaluation of exogenous vs. endogenous selection models. Mar. Biol. 131, 505- 514. 
Yund, P.O., McCartney, M.A., 2016. Family effects on the growth and survival of congeneric blue mussel larvae (Mytilus edulis and M. trossulus). Mar. Biol. 163, 76. 
Table 1. Mating design for the production of pure and hybrid mussels (EE: Mytilus edulis, GG: Mytilus galloprovincialis, EG: $\uparrow$ M. edulis x $\curvearrowright$ M. galloprovincialis, GE: $\uparrow M$. galloprovincialis x $\overbrace{}^{\Uparrow}$ M. edulis).

\begin{tabular}{|c|c|c|c|c|c|c|}
\hline & & & & Male & & \\
\hline & Species & & $\begin{array}{c}M . \\
\text { galloprovincialis }\end{array}$ & $\begin{array}{c}M . \\
\text { edulis }\end{array}$ & $\begin{array}{c}\text { M. } \\
\text { edulis }\end{array}$ & $\begin{array}{c}\text { M. } \\
\text { edulis }\end{array}$ \\
\hline & & Origin & Bouzigues & Floride & Agnas & Yves \\
\hline \multirow{4}{*}{ Female } & $\begin{array}{c}M . \\
\text { galloprovincialis }\end{array}$ & Bouzigues & GG & GE & & \\
\hline & M. edulis & Floride & EG & $\mathrm{EE}$ & & \\
\hline & M. edulis & Agnas & & & $\begin{array}{l}\text { G0- } \\
\text { Agnas }\end{array}$ & \\
\hline & M. edulis & Yves & & & & $\begin{array}{l}\text { G0- } \\
\text { Yves }\end{array}$ \\
\hline
\end{tabular}


Table 2. Pathogens screened from moribund mussels sampled for trials 1 and 2 from April

to September 2015 (positive/number of sample diagnosed)

\begin{tabular}{|l|l|l|c|c|c|c|c|c|}
\hline \multicolumn{1}{|c|}{ Trial } & \multicolumn{1}{|c|}{ Method } & \multicolumn{1}{|c|}{ Pathogen } & April & May & June & July & August & September \\
\hline 1 & QPCR & OsHV-1 & $0 / 9$ & $0 / 8$ & $0 / 5$ & $0 / 3$ & $0 / 9$ & $0 / 2$ \\
\hline 1 & QPCR & V. aestuarianus & $0 / 9$ & $0 / 8$ & $0 / 5$ & $0 / 3$ & $0 / 9$ & $0 / 2$ \\
\hline 1 & QPCR & Splendidus clade & $7 / 9$ & $6 / 8$ & $5 / 5$ & $3 / 3$ & $0 / 9$ & $2 / 2$ \\
\hline 1 & Petri dishes & bacteria & $5 / 5$ & & & & & \\
\hline 1 & Petri dishes and QPCR & Splendidus clade & $3 / 5$ & & & & & \\
\hline 1 & Petri dishes and QPCR & V. aestuarianus & $0 / 5$ & & & & & \\
\hline 1 & histology & Perkinsus sp. & $0 / 5$ & & & & & \\
\hline 1 & histology & Bonamia sp. & $0 / 5$ & & & & & \\
\hline 1 & histology & Marteilia sp. & $0 / 5$ & & & & & \\
\hline 1 & histology & Mikrocytos sp. & $0 / 5$ & & & & & \\
\hline & & & & & & & & \\
\hline & & & & & & & & \\
\hline 2 & QPCR & OsHV-1 & $0 / 12$ & $0 / 19$ & $0 / 8$ & $0 / 8$ & $0 / 10$ & \\
\hline 2 & QPCR & OsHV-1 & & & & & $0 / 15^{\mathrm{a}}$ & \\
\hline 2 & QPCR & V. aestuarianus & $0 / 12$ & $0 / 19$ & $0 / 8$ & $0 / 8$ & $0 / 10$ & \\
\hline 2 & OPCR & Splendidus clade & $10 / 12$ & $17 / 19$ & $7 / 8$ & $6 / 8$ & $3 / 10$ & \\
\hline 2 & Petri dishes & bacteria & $5 / 5$ & & & & $5 / 5^{\mathrm{a}}$ & \\
\hline 2 & Petri dishes and QPCR & Splendidus clade & $3 / 5$ & & & & $0 / 5^{\mathrm{a}}$ & \\
\hline 2 & Petri dishes and QPCR & V. aestuarianus & $0 / 5$ & & & & $0 / 5^{\mathrm{a}}$ & \\
\hline 2 & histology & Perkinsus sp. & $0 / 5$ & & & & $0 / 20^{\mathrm{a}}$ & \\
\hline 2 & histology & Bonamia sp. & $0 / 5$ & & & & $0 / 20^{\mathrm{a}}$ & \\
\hline 2 & histology & Marteilia sp. & $0 / 5$ & & & & $0 / 20^{\mathrm{a}}$ & \\
\hline 2 & histology & Mikrocytos sp. & $0 / 5$ & & & & $0 / 20^{\mathrm{a}}$ & \\
\hline
\end{tabular}

${ }^{a}$ spat. The other individuals sampled were adults. 
Figure 1. Experimental design of trial 1 for the mortality survey for wild adult mussels of Mytilus edulis under laboratory conditions. Separate condition indicates one stock (Agnas or Yves) per tank, whereas both stocks were tested in the same tanks for the common condition. The number of tanks per conditions is represented by the number of tanks drawn ( 3 tanks used for the common condition and so on...). Two hundred mussels were used per stock and per tank.

Figure 2. Experimental design of trial 2 for the mortality survey of Mytilus spp. under laboratory conditions using wild adult mussels (Yves and Agnas stocks) and hatchery-produced spat mussel (G0-Agnas produced from the Agnas stock, G0-Yves produced from the Yves stock, EE: Mytilus edulis, GG: Mytilus galloprovincialis, EG: interspecific hybrid $q$ M. edulis

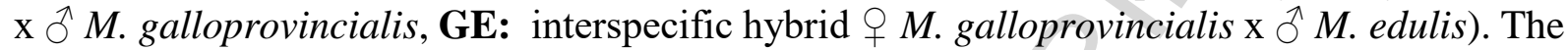
numbers of mussels used per stock are indicated for each stock. For the common condition, the parents of G0-Agnas and G0-Yves were transferred in the tank in May 2015, while hatcheryproduced spat mussels were transferred in June 2015.

Figure 3: Electropherograms corresponding to amplification fragments using Me 15/16 primers and DNA from M. edulis (a), M. galloprovincialis (b) and their reciprocal hybrids (c). Boxes under peaks indicate the estimated length of the amplified fragments.

Figure 4. Seawater temperature from January to November 2015. Stars indicated the main mortality events reported in trials 1 and 2 .

Figure 5. Cumulative mortality ( \pm SD among tanks) of two wild stocks of Mytilus edulis for the separated (A) and mixed conditions (B) at the adult stage in trial 1 from January to November 2015.

Figure 6. Cumulative mortality of wild adult mussel stocks (A) and hatchery-produced spat (B) in trial 2 from January to November 2015. Mytilus edulis (EE), M. galloprovincialis (GG) and their hybrids (EG and GE for $q$ M. edulis $\mathrm{x} \stackrel{\top}{\top} M$. galloprovincialis and $q M$. galloprovincialis $\mathrm{x}$ $\widehat{\jmath}$ M. edulis, respectively). 


\section{Highlights}

- M. edulis that survived a mortality outbreak continued to show mortality in the following year,

- Naïve M. edulis adults had significant mortality only when they were in contact with $M$. edulis that survived a mortality outbreak suggesting a horizontal transmission of a putative causal agent,

- No putative causal agent identified yet, although the bacteria belonging to the Splendidus clade were detected at high prevalence,

- M.edulis spat seems less susceptible than M. edulis adults to mortality,

- M. edulis spat seems more susceptible than M. galloprovincialis spat to mortality, 

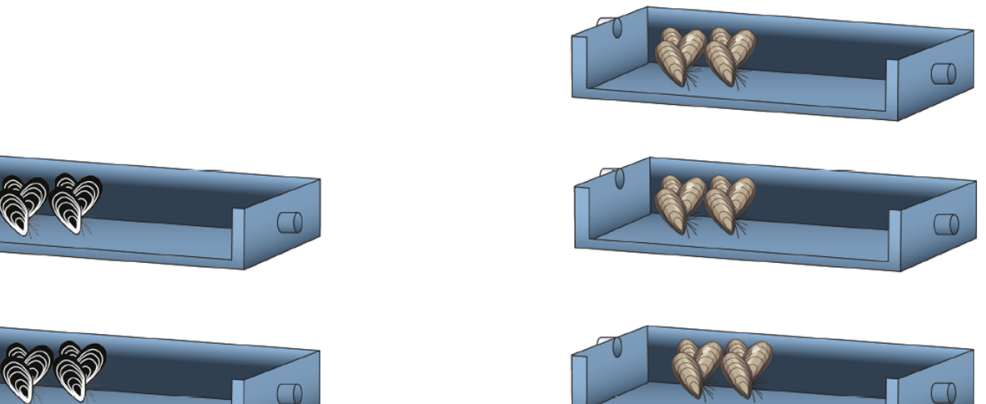

$\mathrm{N}=200$ adult mussels - Yves stock (each tank)

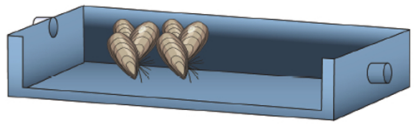

$\mathrm{N}=200$ adult mussels -Agnas stock (each tank)
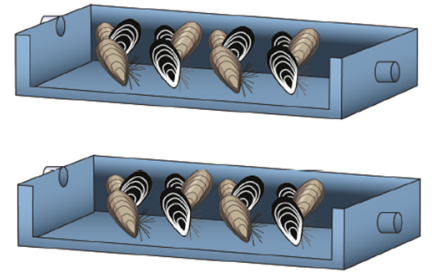

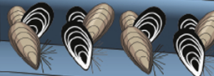

$\mathrm{N}=200$ adult mussels - Agnas stock+ 200 adult mussels -Yves stock (each tank)

Figure 1 


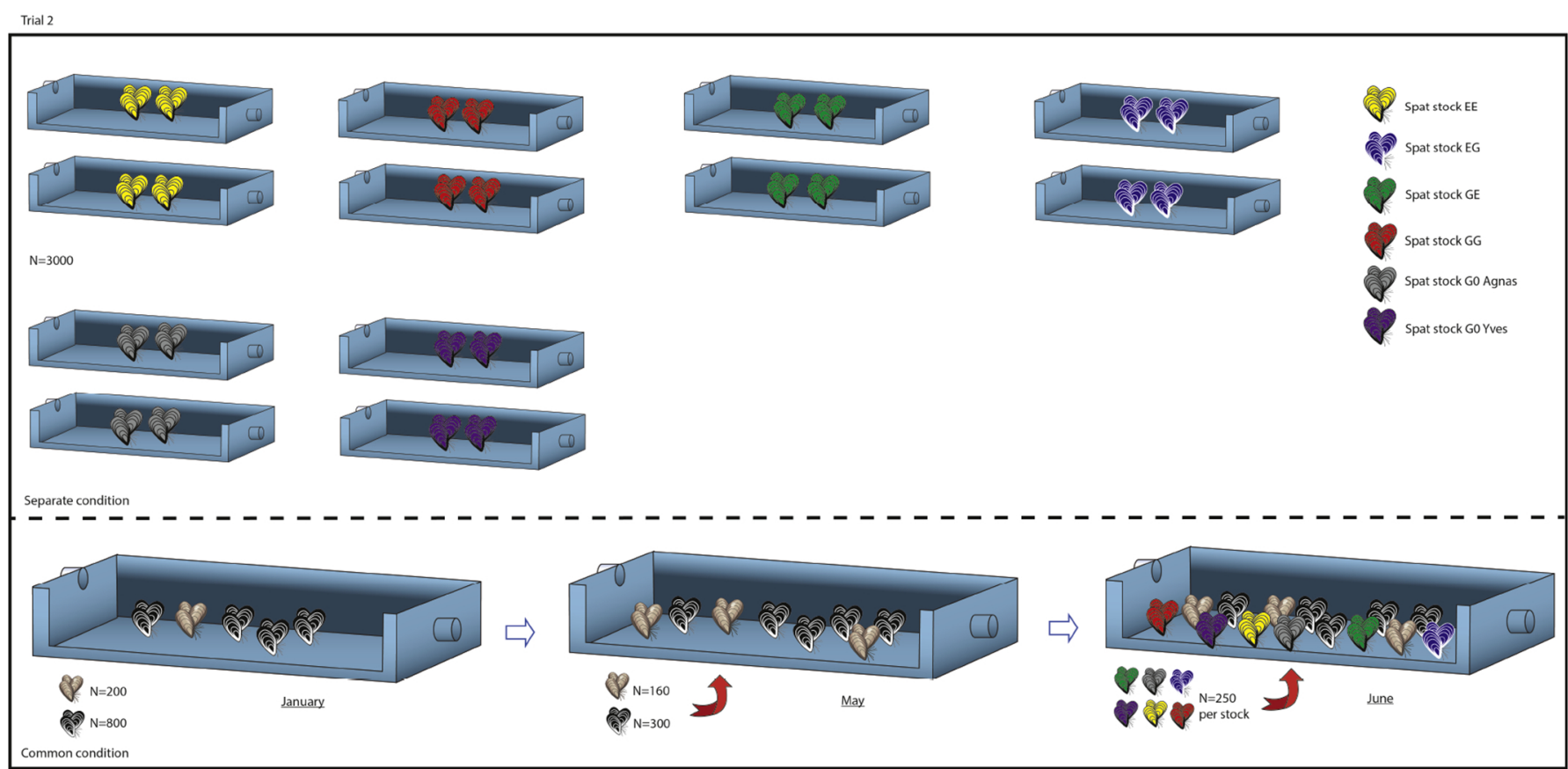

Figure 2 


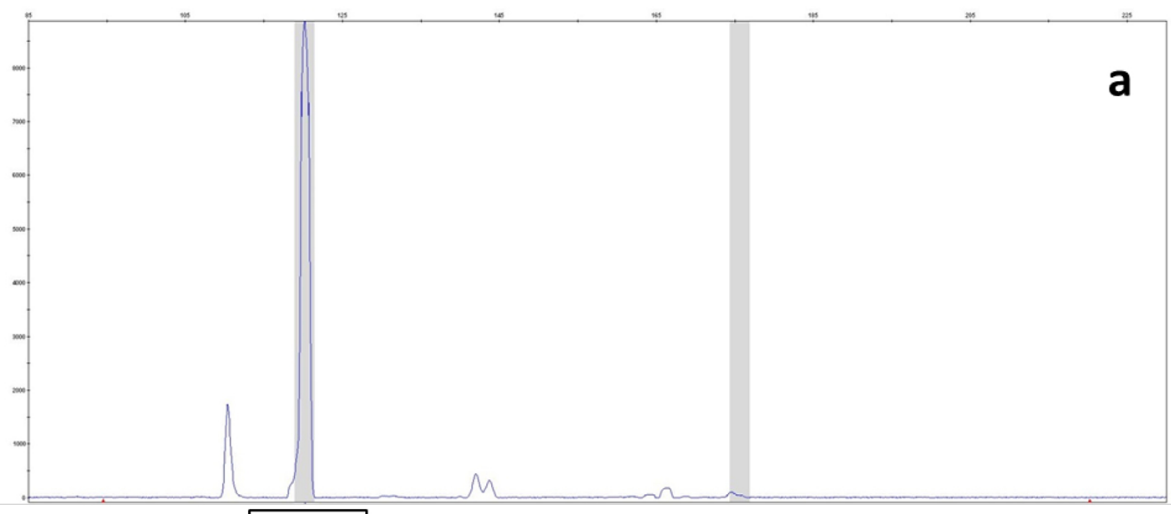

120

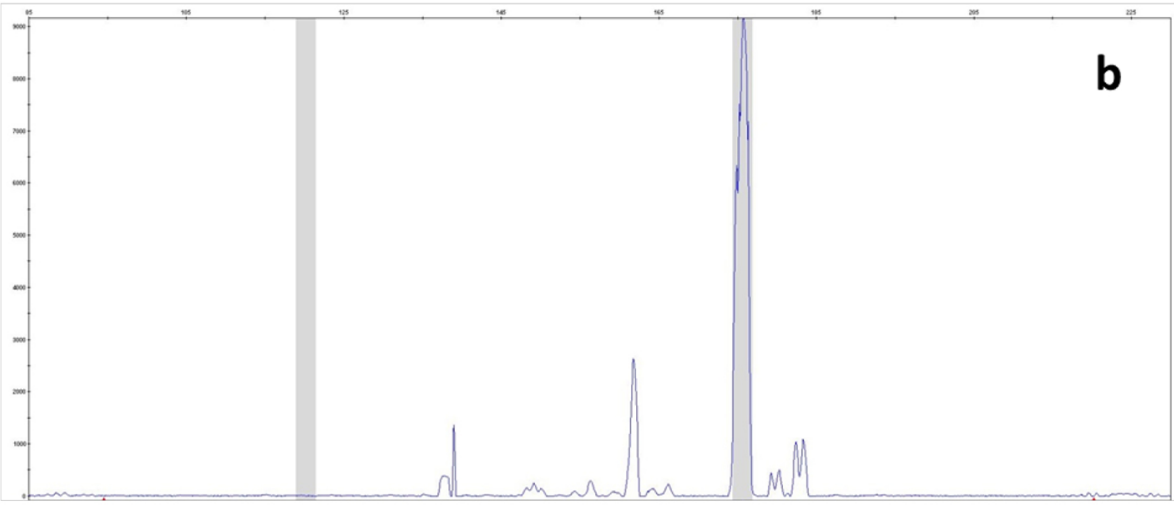

176

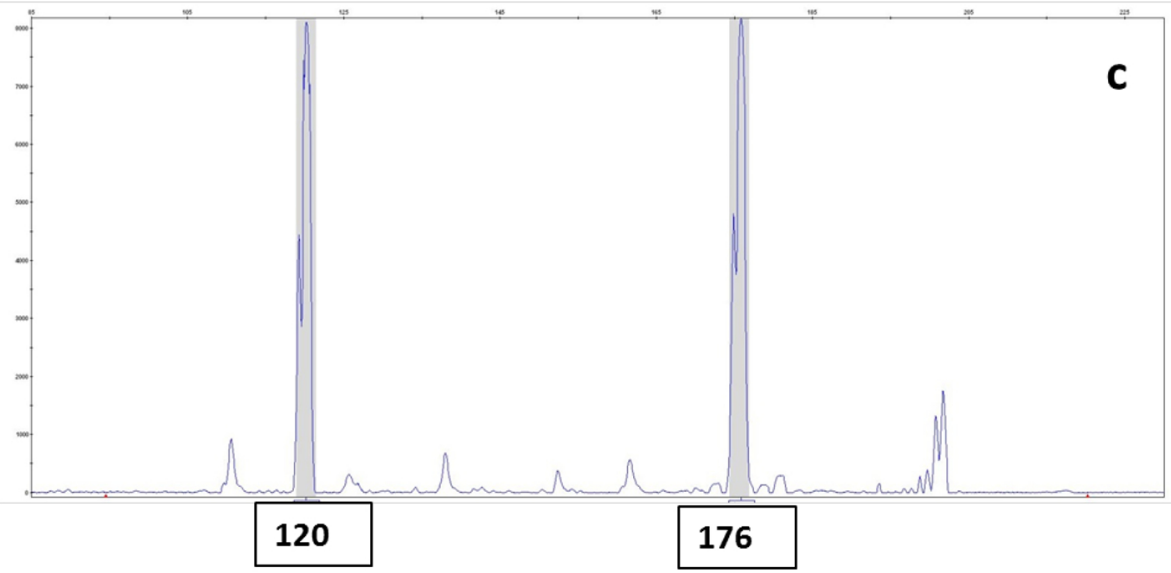

Figure 3 


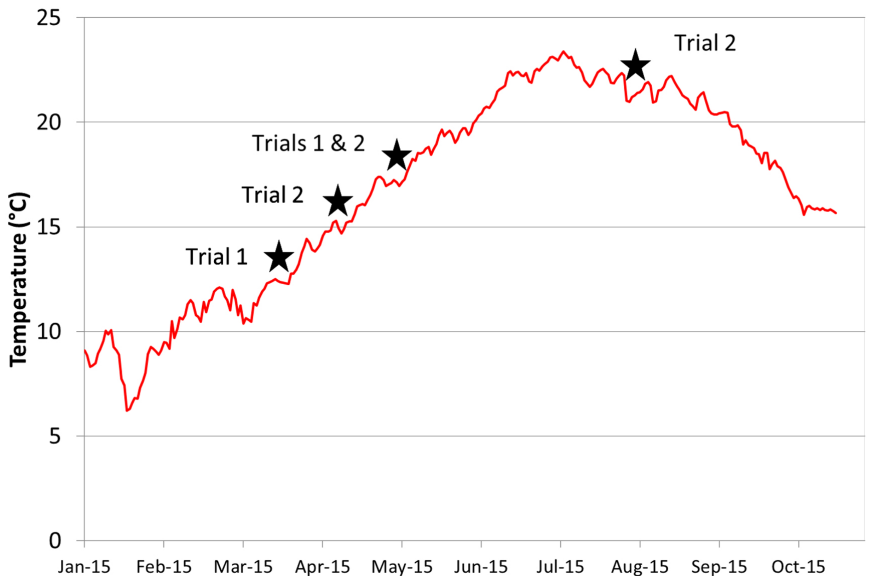

Figure 4 
A

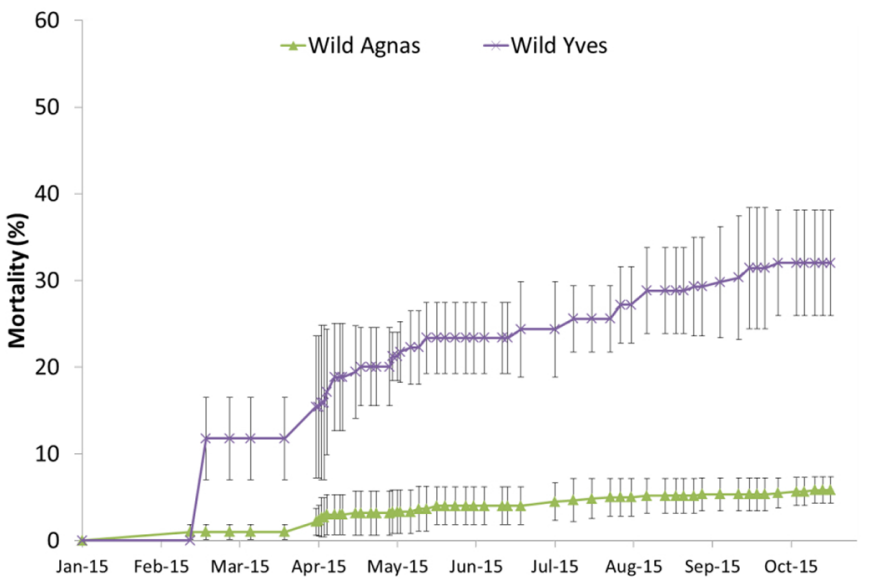

B

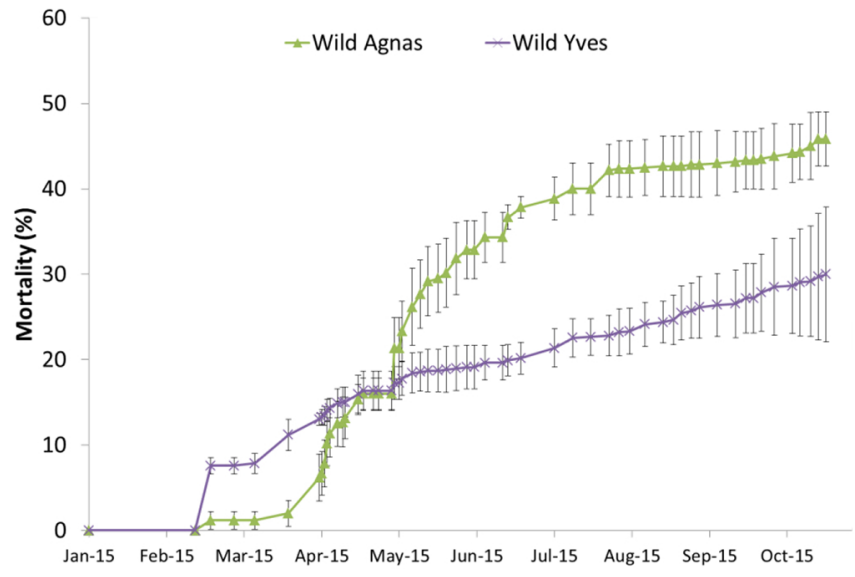

Figure 5 

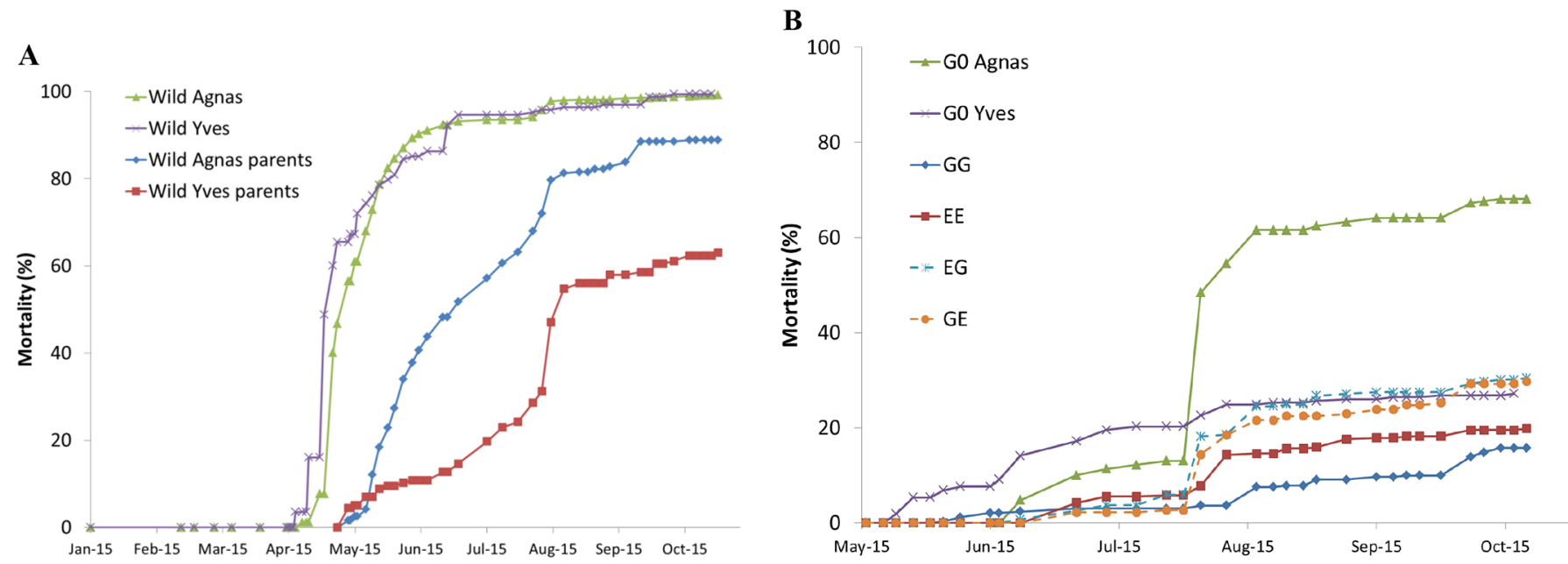

Figure 6 